\title{
Synthesis and Evaluation of Anticonvulsant Activity of 6,8-Dimethoxy-3-methyl-1,2,3,4-tetrahydroisoquinoline in PTZ-Induced Seizure Model in Mice
}

\author{
Yothawathorn Pariyawongsakul ${ }^{1}$, Chamnan Patarapanich ${ }^{2}$, Chantana Boonyarat ${ }^{3}$, \\ Ploenthip Puthongking ${ }^{3^{*}}$ \\ ${ }^{1}$ Graduate School of Pharmaceutical Sciences, Khon Kaen University, Khon Kaen, Thailand \\ ${ }^{2}$ Faculty of Pharmaceutical Sciences, Burapha University, Chonburi, Thailand \\ ${ }^{3}$ Faculty of Pharmaceutical Sciences, Khon Kaen University, Khon Kaen, Thailand \\ Email: "pploenthip@kku.ac.th.
}

Received May 18, 2012; revised June 23, 2012; accepted July 5, 2012

\begin{abstract}
This study we describe the synthesis of a novel structure of anticonvulsant agent as 6,8-dimethoxy-3-methyl-1,2,3,4tetrahydroisoquinoline by using GYKI52466, which was the potent anticonvulsant agent, as the lead molecule. Compound IV was synthesized and anticonvulsant effects was evaluated against Pentylenetetrazole (PTZ)-induced seizure model in mice. The acute anticonvulsant effect was tested with a single dose of 25 and $75 \mu \mathrm{mol} / \mathrm{kg}$ of the synthesis compound. Sodium valproate and normal saline were used as the reference standard and control, respectively. All compounds were injected intraperitoneally to each mouse an hour prior to seizure induced by injection of $60 \mathrm{mg} / \mathrm{kg}$ PTZ and observed their behavior for 30 minutes. The result showed that the $\mathbf{I V}$ at $75 \mu \mathrm{mol} / \mathrm{kg}$ could delay the latency to first twitch and decrease percent mortality compared to control group.
\end{abstract}

Keywords: Anticonvulsant; Pentylenetetrazole; Tetrahydroisoquinoline

\section{Introduction}

Epilepsy is a common chronic neurological disorder affecting individuals of all ages. It is defined as the occurrence of at least one epileptic seizure, unprovoked by any immediate identified cause [1]. There are several ways for the treatment of epilepsies, although antiepileptic drugs (AEDs) remain the most widely utilized treatment [2]. 1-(4-aminophenyl)-4-methyl-7,8-methylenedioxy-5H-2,3benzodiazepine (GYKI52466, 1) is the first compound showed anticonvulsant that act via noncompetitive-AMPA receptor antagonist and was used as a lead for many studies [3-10]. Subsequently, talampanel (2) and CFM-2 (3) was identified, and showed highly active molecule with good results in various animal seizure models [1113]. According to 3D-pharmacophore study of Barreca et al. [11] the simple replacement of diazepine ring with tetrahydropyridine system directed the synthesis toward the 2-acetyl-1-aryl-6,7-dimethoxy-1,2,3,4-tetrahydroisoquinolines (4), which mapped well onto the 3D-pharmacophore hypothesis (two hydrophobic groups, hydrogen bond acceptor feature and one aromatic region in a specific three-dimensional arrangement) and shows an anti-

"Corresponding author. convulsant activity more potent than 1 and 2 [14].

According to the structure-activity relationship (SAR) studies, modification by substitute halogens (ex. $\mathrm{Cl}, \mathrm{Br}$ ) at 4'-position on phenyl ring appears to improve the anticonvulsant activity [15-17]. Since there was the study showed that mono-substitution of methoxy showed lower efficacy than the corresponding 6,7-disubstituted derivative as one chemical feature of model is not mapped.

In this study we designed to synthesize IV with the introduction of 6,8-dimethoxy which expect to be well mapped on 3D-pharmacophore hypothesis and 3-methyl for analogy with 2 (Figure 1). Moreover, we introduce $\mathrm{Cl}$ at 4'-position on phenyl ring in expected to improve pharmacological and pharmacokinetic of the compound. The aims are to explore if these modification could influent the anticonvulsant effect by primary screen anticonvulsant activity via Pentylenetetrazole (PTZ)-induced seizure model.

\section{Result and Discussions}

\subsection{Chemistry}

The synthesis of the study compound was accomplished as shown in Scheme 1. The 3,5-dimethoxybenzaldehyde will 

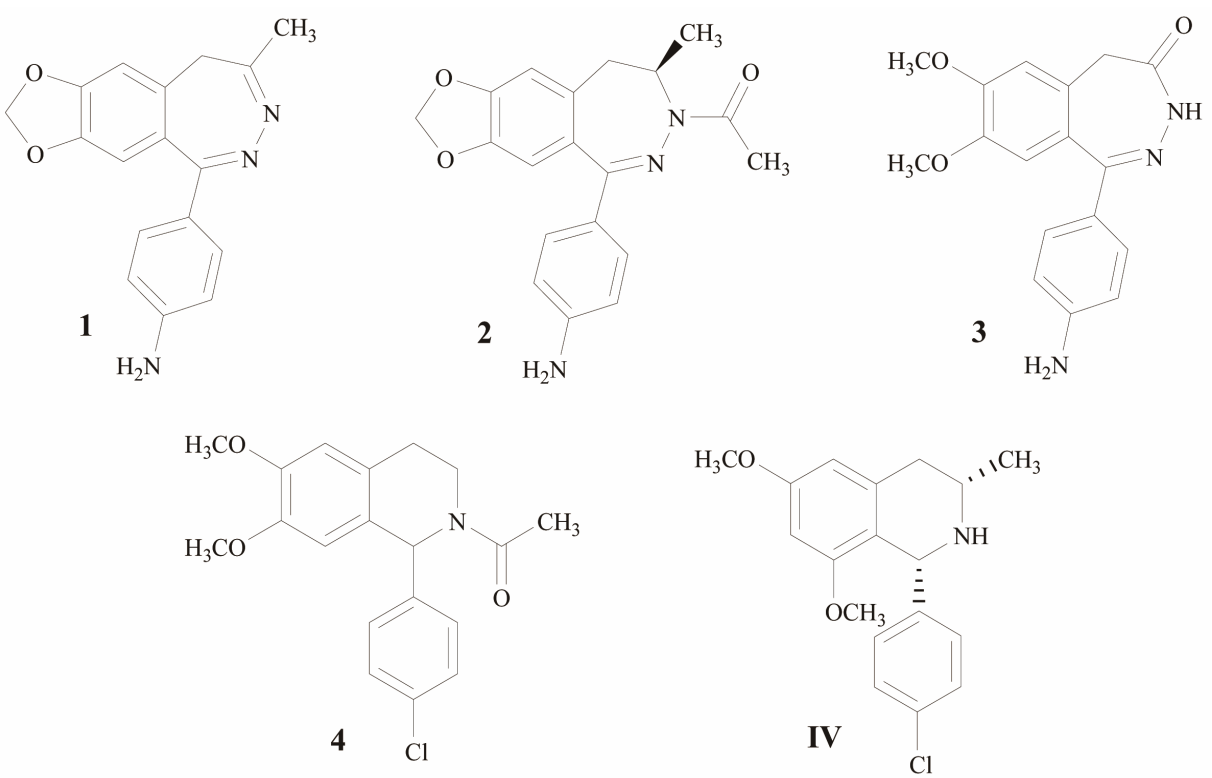

Figure 1. Non-competitive AMPA receptor antagonists.<smiles>COc1cc(OC)cc(C(=O)I)c1</smiles>

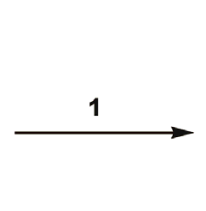<smiles>COc1cc(C=C(C)C)cc(OC)c1</smiles>

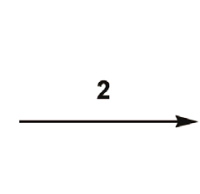<smiles>COc1cc(CC(C)[N+](=O)[O-])cc(OC)c1</smiles>

I
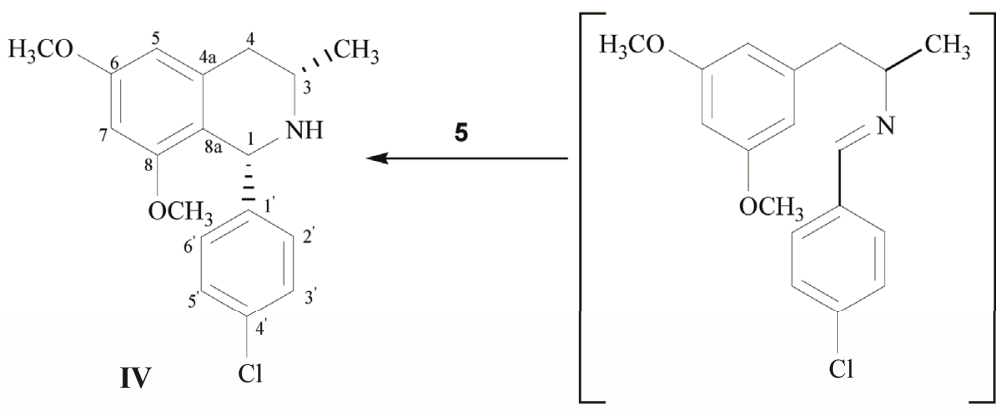

(IIIa; intermediate)<smiles>O=Cc1ccc(Cl)cc1</smiles>

$\mathrm{H}_{3} \mathrm{CO}$

$\downarrow$

II

Scheme 1. Reagent and conditions; (1) $\mathrm{CH}_{3} \mathrm{CH}_{2} \mathrm{NO}_{2}, \mathrm{NH}_{4} \mathrm{OAc}$, reflux; (2) $\mathrm{NaBH}_{4}, \mathrm{SiO}_{2}, \mathrm{IPA} / \mathrm{CHCl}, \mathrm{rt}$; (3) $\mathrm{H}_{2}, 10 \% \mathrm{Pd} / \mathrm{C}$, $\mathrm{MeOH;} \mathrm{(4)} \mathrm{4-Chlorobenzaldehyde,} \mathrm{toluene,} \mathrm{reflux;} \mathrm{(5)} \mathrm{TFA,} \mathrm{MeOH,} \mathrm{reflux.}$

be used as starting material. It was treated with nitroethane and ammonium acetate (1 eq.) in order to obtain I as yellow crystalline solid. The ${ }^{1} \mathrm{H}$-NMR of the product showed the singlet pattern of methoxy group at $\delta 3.81$ ppm and showed the H-aromatic signal at $\delta 6.50-6.54$ ppm. The product was confirmed successful reaction by the singlet signal of proton position 2 showed at $\delta 8.00$ ppm and carbon signal showed at $\delta 148.5 \mathrm{ppm}$. The methyl substitute showed proton singlet at $\delta 2.44 \mathrm{ppm}$ and carbon signal at $\delta 14.5 \mathrm{ppm}$. Secondly, it was further reduced by $\mathrm{NaBH}_{4}$ (4 eq.) to give II as yellowish oil. The product was confirmed by multiplet proton signal of position 1 showed at $\delta 4.75 \mathrm{ppm}$. The proton signal of position 2 showed doublet of doublet pattern at $\delta 2.90(J=$ 7.6, $13.8 \mathrm{~Hz})$ and $3.22(J=6.4,13.8 \mathrm{~Hz})$ ppm. Moreover, proton signal of methyl group was up-field shifted from $\delta 2.44$ to $1.50 \mathrm{ppm}$. In ${ }^{13} \mathrm{C}-\mathrm{NMR}$, the carbon signal of position 1 was up field shifted from $\delta 133.95$ ppm to 
$84.62 \mathrm{ppm}$ and position 2 from 148.55 to $41.75 \mathrm{ppm}$. Alternation of nitro group to amine group was performed by the hydrogenation under hydrogen gas with $10 \% \mathrm{Pd} / \mathrm{C}$, III can be obtained as yellow oil. The III was confirmed successful hydrogenation by the up-filed shift of the proton signal at position 1 from $\delta 4.17$ to $3.16 \mathrm{ppm}$ and amine group showed the broad singlet signal at $\delta 2.09 \mathrm{ppm}$.

Compound III was further refluxed with 4-chlorobenzaldehyde (5 eq.) in toluene to give yellowish oil product of imine intermediate (Schiff base). The imine intermediate is unstable in the air and high moisture condition. Therefore, the next cyclization step will be continuously performed via Pictet-Spengler synthetic pathway in the presence of TFA (1.5 eq.) to give IV as yellow solid. The IV can be isolated by conventional column chromatography. The complete cyclization was confirmed by the 1D and 2D-NMR. The proton signal of position 4 in compound IV at $\delta 2.6 \mathrm{ppm}$ showed the axial-axial interaction $\left(J_{a x}\right)$ between proton at positions 3 and 4 which had coupling constant equal to $10.8 \mathrm{~Hz}$, while represented geminal coupling $\left(J_{\text {gem }}\right)$ as $15.6 \mathrm{~Hz}$ of both protons at position 4. Furthermore, proton signal of position 4 at $\delta 2.7 \mathrm{ppm}$ represented the axial-equatorial interaction $\left(J_{a x}\right)$ which had coupling constant equal to $2.4 \mathrm{~Hz}$. These difference $J$ values suggested that 3-methyl group of IV should be in equatorial configuration. And stereochemistry of IV was confirmed as cis-isomer by using Nuclear Overhauser effect (NOE) method. The NOE data of IV showed strong exchanges of magnetization among the $3-\mathrm{H}$ and $1-\mathrm{H}$ indicated that these protons should be in a cis-isomer (Figure 2).

\subsection{Anticonvulsant Activity}

The anticonvulsant effects were evaluated against PTZinduced seizure model in ICR mice (Table 1). The results were compared with standard anticonvulsant, valproic acid (VPA). The dose for VPA (200 $\mathrm{mg} / \mathrm{kg}$ ) was based on experimental evidence that dose from 100 to 400 $\mathrm{mg} / \mathrm{kg}$ (i.p.) are effective in animal model [18,19]. PTZ is a convulsant chemical agent frequently use in experimental models for induction of seizure [20]. According to various studies using PTZ-induced seizure model, the dose of PTZ varied from 50 to $125 \mathrm{mg} / \mathrm{kg}$. We decide to

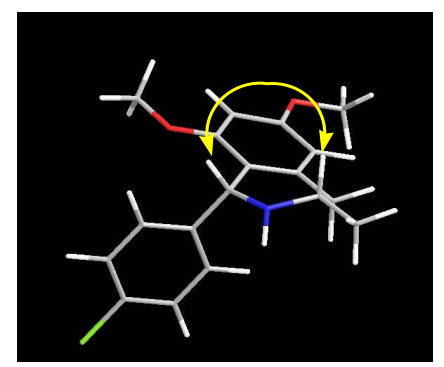

Figure 2. NOE interaction for IV.
Table 1. Anticonvulsant activity of IV against PTZ-induced seizure model.

\begin{tabular}{|c|c|c|c|}
\hline Compounds & Latent period (s) & Mortality (\%) & $P$-values \\
\hline PTZ + IV $25 \mu \mathrm{mol}$ & $84.6 \pm 3.8$ & 40 & $>0.05$ \\
\hline PTZ + IV $75 \mu \mathrm{mol}$ & $95.8 \pm 15.1$ & 0 & $<0.05$ \\
\hline $\mathrm{PTZ}+\mathrm{VPA}$ & $114.2 \pm 21.8$ & 0 & $<0.05$ \\
\hline PTZ (Control) & $68.0 \pm 15.9$ & 50 & \\
\hline
\end{tabular}

use $60 \mathrm{mg} / \mathrm{kg}$ PTZ by i.p. injection as it was the dose that produces jerks, myoclonus and clonic generalized seizures in $100 \%$ of control animals. Moreover, it was the dose that is between the $50 \%$ effective dose $\left(E D_{50}\right)$ of 33 $\mathrm{mg} / \mathrm{kg}$ [21].

In this study, anticonvulsant effect of IV was evaluated after i.p. administration against PTZ-induced seizure in ICR mice. We observed that in control group which mice received $60 \mathrm{mg} / \mathrm{kg}$ PTZ in saline, all mice showed seizure and $50 \%$ death. Pretreatment of IV $75 \mu \mathrm{mol} / \mathrm{kg}$ could $100 \%$ protect the mortality of mice, however mice still have seizure in all stage. While, pretreatment with VPA gave $100 \%$ protection. Furthermore, the latency to the first twitch, we found that the latency period was increased in groups pretreatment with IV and VPA. Moreover, a significant increase in the latent period was observed in the dosage of $75 \mu \mathrm{mol} / \mathrm{kg}$ IV $(95.8 \pm 15.1$ as compared to $68.0 \pm 15.9$ seconds in the control group).

\section{Experimentals}

Chemicals were purchased from Fluka and Merck from Germany as synthesis grade. Reactions were monitored by TLC Silicagel $60 \mathrm{~F}_{254}$ (Merk, Germany) and were visualized under Ultraviolet light at $254 \mathrm{~nm}$. Iodine vapors were also used for the spot detection. All melting points were recorded on Electrothermal melting point apparatus. Nuclear magnetic resonance $\left({ }^{1} \mathrm{H}-\mathrm{NMR},{ }^{13} \mathrm{C}-\right.$ NMR and 2D-NMR) spectra were recorded in $\mathrm{CDCl}_{3}$ on Varian NMR-400 MHz Spectrometer (Faculty of Science, Khon Kaen University, Khon Kaen, Thailand. Chemical shifts are expressed in $\delta$ (ppm) relative to TMS as the internal standard and coupling constants (J) are in hertz.

\subsection{Synthesis}

2-(3',5'-Dimethoxyphenyl)-1-methyl-1-nitroethene (I).

Ammonium acetate $(2.4 \mathrm{mmol}, 207.9 \mathrm{mg})$ was slowly added to the mixture of 3,5-dimethoxybenzaldehyde ( $2.4 \mathrm{mmol}, 400 \mathrm{mg})$ in nitroethane $(6 \mathrm{~mL})$. The mixture was refluxed for 6 hours. The reaction was worked-up by extracted with water $(100 \mathrm{~mL})$ and EtOAc $(3 \times 100$ $\mathrm{mL}$ ), the organic layer was dried with $\mathrm{Na}_{2} \mathrm{SO}_{4}$ anh. and 
filtered out. The organic layer was then concentrated under rotary evaporator and purification by recrystallization with methanol to afford yellow crystalline solid. Yield: $82 \%$, mp $88.2-90.0^{\circ} \mathrm{C}, R_{f}=0.5$ in Hexane: EtOAc (5:1). ${ }^{1} \mathrm{H}-\mathrm{NMR}(\delta, \mathrm{ppm}): 2.44\left(1 \mathrm{H}, \mathrm{s}, \mathrm{CH}_{3}-3\right)$, 3.81 (2 × $3 \mathrm{H}, \mathrm{s}, \mathrm{OCH}_{3}-3^{\prime}$ and 5'), 6.50 (1 H, s, H-4'), 6.54 (2 H, s, H-2' and H-6'), 8.00 (1H, s, H-2). ${ }^{13} \mathrm{C}-\mathrm{NMR}$ ( $\delta$, ppm): $14.54\left(\underline{\mathrm{CH}}_{3}-1\right), 55.89\left(\mathrm{OCH}_{3}-3\right.$ and 5$), 102.13$ (C-4), 108.31 (C-2' and C-6'), 133.95 (C-1), 134.58 (C-1), 148.55 (C-2), 161.36 (C-3’ and C-5').

2-(3',5'-Dimethoxyphenyl)-1-methyl-1-nitroethane (II).

The mixture of I (3.64 mmol, $811.2 \mathrm{mg}$ ) was dissolved in the mixture of $\mathrm{CHCl}_{3}$ : IPA in a ratio of $1: 1$ (30 $\mathrm{mL}$ ). Then, silica gel (5 g) was slowly added to the mixture. After that, $\mathrm{NaBH}_{4}$ (14.55 mmol, $550.0 \mathrm{mg}$ ) was slowly added over 1 hour in ice-bath. Then, the mixture was stirred at room temperature for 12 hours. The reaction was stopped by slowly added glacial acetic acid until there were no more bubble gases. The silica gel was filtered out. The excess glacial acetic acid was neutralized with $5 \% \mathrm{NaHCO}_{3}$. The organic layer was then further washed with water $(3 \times 100 \mathrm{~mL})$ and dried over $\mathrm{Na}_{2} \mathrm{SO}_{4}$ anh. and filtered out. The solution was removed under reduced pressure to give yellow oil product. Yield: $94 \%, R_{f}=0.4$ in Hexane : EtOAc (5:1). ${ }^{1} \mathrm{H}-\mathrm{NMR}$ ( $\delta$, ppm): 1.50 (3H, d, $\left.J=6.8 \mathrm{~Hz}, \mathrm{CH}_{3}-3\right), 2.90$ (1 H, dd, $\left.J_{\text {gem }}=13.8 \mathrm{~Hz}, J_{\text {vic }}=7.6 \mathrm{~Hz}, \mathrm{H}-2\right), 3.22\left(1 \mathrm{H}, \mathrm{dd}, J_{\text {gem }}=\right.$ $\left.13.8 \mathrm{~Hz}, J_{\text {vic }}=6.4 \mathrm{~Hz}, \mathrm{H}-2\right), 3.73\left(2 \times 3 \mathrm{H}, \mathrm{s}, \mathrm{OCH}_{3}-3\right.$ ' and 5'), 4.72 - 4.77 (1 H, m, H-1), 6.29 (2 H, s, H-2' and 6'), 6.34 (1 H, s, H-4'). ${ }^{13} \mathrm{C}-\mathrm{NMR}$ ( $\delta$, ppm): 19.25 (1- $\left.\underline{\mathrm{CH}}_{3}\right), 41.75$ (C-2), $55.69\left(\mathrm{O}^{-} \mathrm{H}_{3}-3^{\prime}\right.$ and 5'), 84.62 (C-1), 99.56 (C-4'), 107.48 (C-2' and C-6'), 138.14 (C-1'), 161.46 (C-3' and C-5').

2-(3',5'-Dimethoxyphenyl)-1-methylethylamine (III).

A solution of II (16.6 mmol, $3.74 \mathrm{~g})$ in ethanol (20 mL) was hydrogenated over $10 \% \mathrm{Pd} / \mathrm{C}$ (10\% mass of starting material). After the complete reaction, the catalyst was filtered out by wash with ethanol. The filtrate was removed under reduced pressure and further extracted with EtOAc $(100 \mathrm{~mL})$ and $0.5 \mathrm{~N} \mathrm{HCl}(3 \times 100 \mathrm{~mL})$. The aqueous layer was basified to $\mathrm{pH}=9-10$ by ammonia solution. After that, the basified solution was extracted with EtOAc $(3 \times 100 \mathrm{~mL})$. The organic layer was dried over $\mathrm{Na}_{2} \mathrm{SO}_{4}$ anh. and removed under reduced pressure to obtain yellow oil product (III). Yield: $56 \%, R_{f}=0.12$ in $\mathrm{CHCl}_{3}: \mathrm{MeOH}(10: 0.5) .{ }^{1} \mathrm{H}-\mathrm{NMR}(\delta, \mathrm{ppm}): 1.11$ (3 H, d, $\left.J=6.8 \mathrm{~Hz}, \mathrm{CH}_{3}-3\right), 2.09$ (2H, s, $\left.\mathrm{NH}_{2}\right), 2.46$ (1 H, dd, $J_{\text {gem }}$ $\left.=13.2 \mathrm{~Hz}, J_{\text {vic }}=8.0 \mathrm{~Hz}, \mathrm{H}-2\right), 2.64\left(1 \mathrm{H}, \mathrm{dd}, J_{\text {gem }}=13.2\right.$ $\left.\mathrm{Hz}, J_{\text {vic }}=5.2 \mathrm{~Hz}, \mathrm{H}-2\right)$, 3.14-3.19 (1 H, m, H-1), 3.75 (2 $\times 3 \mathrm{H}, \mathrm{s}, \mathrm{OCH}_{3}-3^{\prime}$ and 5'), 6.30 (2 H, s, H-2' and 6'), 6.32 (1H, s, H-4'). ${ }^{13} \mathrm{C}-\mathrm{NMR}(\delta, \mathrm{ppm}): 23.98\left(1-\mathrm{CH}_{3}\right), 47.33$ (C-2), 48.71 (C-1), 55.65 (OCH $_{3}-3$ ' and 5'), 98.54 (C-4'), 107.65 (C-2' and C-6'), 142.48 (C-1'), 161.18 (C-3' and C-5').
N-(4-Chlorobenzylidene)-2-(3',5'-dimethoxyphenyl)1-methylethylamine (IIIa).

4-Chlorobenzaldehyde (6.65 mmol, $931 \mathrm{mg}$ ) was added to a solution of III (1.33 mmol, $259 \mathrm{mg}$ ) in toluene (20 mL). The reaction mixture was refluxed under DeanStark separator for 6 hours. The solvent was removed under rotary evaporator apparatus to give yellowish oil product (IIIa) as intermediate. The compound was then continuously processed in the next step.

1-(4'-Chlorophenyl)-6,8-dimethoxy-3-methyl-1,2,3,4tetrahydroisoquinoline (IV).

Trifluoroacetic acid (1.5 eq) was added to IIIa in methanol $(10 \mathrm{~mL})$ and refluxed for 2.5 hours. After that, the reaction was cooled down at room temperature and extracted with water $(100 \mathrm{~mL})$ and EtOAc $(3 \times 100 \mathrm{ml})$. Finally, dried the organic layer over $\mathrm{Na}_{2} \mathrm{SO}_{4}$ anh. and concentrated under reduced pressure. Purification by column chromatography to obtain yellow solid. Yield: 57\%, mp: $80.5^{\circ} \mathrm{C}-82.0^{\circ} \mathrm{C}, R_{f}=0.53$ in Hexane: EtOAC (1:1). ${ }^{1} \mathrm{H}-\mathrm{NMR}\left(\mathrm{CDCl}_{3}\right) \delta: 1.20\left(3 \mathrm{H}, \mathrm{d}, J=6 \mathrm{~Hz}, \mathrm{CH}_{3}-3\right)$, $1.25(1 \mathrm{H}, \mathrm{bs}, \mathrm{NH}), 2.60\left(1 \mathrm{H}\right.$, dd, $J_{g e m}=15.6 \mathrm{~Hz}, J_{a x}=$ $\left.10.8 \mathrm{~Hz}, \mathrm{H}_{\mathrm{ax}}-4\right), 2.70\left(1 \mathrm{H}, \mathrm{dd}, J_{\text {gem }}=15.6 \mathrm{~Hz}, J_{\text {eq }}=2.8\right.$ $\left.\mathrm{Hz}, \mathrm{H}_{\mathrm{eq}}-4\right), 2.98$ - 3.07 (1 $\left.\mathrm{H}, \mathrm{m}, \mathrm{H}-3\right), 3.38$ (3 H, s, $\left.\mathrm{OCH}_{3}-8\right)$, 3.79 (3 H, s, $\left.\mathrm{OCH}_{3}-6\right), 5.13$ (1 H, s, H-1), 6.22 (1 H, s, H-7), 6.28 (1 H, s, H-5), 7.12 - 7.21 (4 H, Aromatic-H). ${ }^{13} \mathrm{C}-\mathrm{NMR}(\delta, \mathrm{ppm}): 21.77\left(\mathrm{CH}_{3}-3\right), 38.91$ (C-4), 48.97 (C-3), $55.00 \quad\left(\mathrm{OC}_{3}-8\right), 55.24\left(\mathrm{OCEH}_{3}-6\right)$, 58.38 (C-1), 97.20 (H-7), 104.49 (C-5), 118.39 (C-8a), 128.40 (C-3' and 5'), 128.84 (C-2' and 6'), 132.08 (C-4'), 138.45 (C-4a), 144.60 (C-1'), 157.55 (C-8), 159.28 (C-6).

\subsection{Anticonvulsant Activity}

Anticonvulsant activity was performed on five-week male ICR mice weigh 30 g - 35 g (Mahidol University, Thailand). The animal were acclimatized in the laboratory in a ventilated room at the ambient temperature of $25^{\circ} \mathrm{C}$ on a natural light/dark cycle for at least one week prior to the experiments. Food and water were provided. Experiments were completed within a week to minimize the effect of increasing age on seizure susceptibility. In all experiments, each animal was used for only once and the experiments were carried out between 9.00 a.m.-6.00 p.m. The experiment was approved by Animals Ethics Committee of Khon Kaen University based on the Ethic of Animal Experimentation of National Research Council of Thailand.

\subsection{Anticonvulsant Activity against PTZ-Induced Seizure Model}

All compounds were fleshly prepared. VPA and PTZ were was dissolved in $15 \%$ tween 80 and normal saline, respectively. The method was modified from Agarwal et 
al. [22]. PTZ in a dose $60 \mathrm{mg} / \mathrm{kg}$ was intraperitoneally injected after 45 minutes administration of normal saline, IV in a dose of $25,75 \mu \mathrm{mol} / \mathrm{kg}$ or valproic acid 200 $\mathrm{mg} / \mathrm{kg}$. All compounds were injected in a volume of 0.01 $\mathrm{mL} / \mathrm{g}$ body weight. In the control, PTZ was injected 45 minutes after the first administration of saline. The behavior of the mice was observed and recorded for 30 minutes after PTZ injection and subsequently analyzed. Time latencies for generalized clonus was measured. The absence of seizures within $30 \mathrm{~min}$, the latency time was taken as $1800 \mathrm{sec}$. Latencies were calculated as the time between PTZ injections to the onset of these stages. Generalizes clonus was described by the involvement of all four limbs and tail, rearing, wild running and jumping, sudden loss of upright posture and autonomic signs [23].

\subsection{Statistical Analysis}

The data are expressed as means \pm standard error (SE). The correlations were carried out by ANOVA followed by Dunnett's test and Kruskal-Wallis nonparametric oneway analysis of variance. SigmaStat 3.11 software was used for statistical analysis and probability value of less than 0.05 was accepted as statistically significant.

\section{Conclusion}

We prepared a new core structure of anticonvulsant agent as 6,8-dimethoxy-3-methyl-1,2,3,4-tetrahydroisoquinoline bearing a pharmacophoric fragment of GYKI52466. The data revealed that the compound IV in the dosage of 75 $\mu \mathrm{mol} / \mathrm{kg}$ was able to increase the latency period and decrease mortality in preliminary screening PTZ-induced seizure model in mice. On the basis of the results obtained with the new compound, IV could present new core structure for further chemical modification for anticonvulsant agent.

\section{Acknowledgements}

Financial supports for this work were provided by the SubCluster of Integrated Multidisciplinary Researches in Health Sciences (MIH-2554-M-12, MIH-55-MR-11) and Graduate Research Fund Academic Year 2011 (54211125) from Khon Kaen University, Thailand. The authors grateful to Prof. Naoki Saito and Prof. Akinori Kubo, Meiji Pharmaceutical University, Japan, for supporting 3,5-dimethoxybenzaldehyde and $\mathrm{Pd} / \mathrm{C}$ and Department of Pharmaceutical chemistry, Faculty of Pharmaceutical Sciences, Chulalongkorn University, Bangkok, Thailand, for supporting Parr hydrogenation apparatus in the preparation of compound III.

\section{REFERENCES}

[1] R. S. Fisher, W. van Emde Boas, W. Blume, C. Elger, P.
Genton, P. Lee and J. J. Engel, "Epileptic Seizures and Epilepsy: Definitions Proposed by the International League against Epilepsy (ILAE) and the International Bureau for Epilepsy (IBE),” Epilepsia, Vol. 46, No. 4, 2005, pp. 470472. doi:10.1111/j.0013-9580.2005.66104.X

[2] A. C. Gerlach and J. L. Krajewski, “Antiepileptic Drug Discovery and Development: What Have We Learned and Where Are We Going?” Pharmaceuticals, Vol. 3, No. 9, 2010, pp. 2884-2899. doi:10.3390/ph3092884

[3] A. Chimirri, G. De Sarro, A. De Sarro, R. Gitto, S. Grasso, S. Quartarone, M. Zappalà, P. Giusti, V. Libri, A. Constanti and A. G. Chapman, "1-Aryl-3,5-dihydro4H-2,3-benzodiazepin-4-ones: Novel AMPA Receptor Antagonists,” Journal of Medicinal Chemistry, Vol. 40, No. 8, 1997, pp. 1258-1269. doi:10.1021/jm960506l

[4] A. Chimirri, G. De Sarro, A. De Sarro, R. Gitto, S. Quartarone, M. Zappalà, A. Constanti and V. Libri, "3,5Dihydro-4H-2,3-benzodiazepine-4-thiones: A New Class of AMPA Receptor Antagonists," Journal of Medicinal Chemistry, Vol. 41, No. 18, 1998, pp. 3409-3416. doi:10.1021/jm9800393

[5] M. Zappalà, R. Gitto, F. Bevacqua, S. Quartarone, A. Chimirri, M. Rizzo, G. D. Sarro and A. D. Sarro, "Synthesis and Evaluation of Pharmacological and Pharmacokinetic Properties of $11 \mathrm{H}-[1,2,4]$ triazolo[4,5-c][2,3] benzodiazepin-3(2H)-ones," Journal of Medicinal Chemistry, Vol. 43, No. 25, 2000, pp. 4834-4839. doi:10.1021/jm001012y

[6] M. Zappalà, G. Postorino, N. Micale, S. Caccamese, N. Parrinello, G. Grazioso, G. Roda, F. S. Menniti, G. D. Sarro and S. Grasso, "Synthesis, Chiral Resolution, and Enantiopharmacology of a Potent 2,3-benzodiazepine Derivative as Noncompetitive AMPA Receptor Antagonis," Journal of Medicinal Chemistry, Vol. 49, No. 2, 2006, pp. 575-581. doi:10.1021/jm050552y

[7] Y. Wang, C. S. Konkoy, V. I. Ilyin, K. E. Vanover, R. B. Carter, E. Weber, J. F. Keana, R. M. Woodward and S. X. Cai, "Synthesis of 7,8-(Methylenedioxy)-1-phenyl-3,5-dihydro-4H-2,3-benzodiazepin-4-ones as Novel and Potent Noncompetitive AMPA Receptor Antagonists,” Journal of Medicinal Chemistry, Vol. 41, No. 14, 1998, pp. 26212625. doi:10.1021/jm980168j

[8] G. Abrahám, S. Sólyom, E. Csuzdi, P. Berzsenyi , I. Ling, I. Tarnawa, T. Hámori, I. Pallagi, K. Horváth, F. Andrási, G. Kapus, L. G. J. Hársing, I. Király, M. Patthy and G. Horváth, "New Noncompetitive AMPA Antagonists," Bioorganic \& Medicinal Chemistry, Vol. 8, No. 8, 2000, pp. 2127-2143 doi:10.1016/S0968-0896(00)00133-4

[9] T. Hámore, S. Sólyom, P. Berzsenyi, F. Andrási and I. Tarnawa, "Structural Analogues of Some Highly Active Non-Competitive AMPA Antagonists,” Bioorganic \& Medicinal Chemistry Letters, Vol. 10, No. 9, 2000, pp. 899902. doi:10.1016/S0960-894X(00)00117-7

[10] S. Grasso, G. De Sarro, A. De Sarro, N. Micale, M. Zappalà, G. Puia, M. Baraldi and C. D. Micheli, "Synthesis and Anticonvulsant Activity of Novel and Potent 2,3benzodiazepine AMPA/Kainate Receptor Antagonists," Journal of Medicinal Chemistry, Vol. 42, 1999, pp. 44144421. doi:10.1021/jm991086d 
[11] J. J. Luszczki, “Third-Generation Antiepileptic Drugs: Mechanisms of Action, Pharmacokinetics and Interactions,” Pharmacological Reports, Vol. 61, No. 2, 2009, pp. 197-216

[12] M. L. Barreca, R. Gitto, S. Quartarone, D. L. Luca, G. D. Sarro and A. Chimirri, "Pharmacophore Modeling as an Efficient Tool in the Discovery of Novel Noncompetitive," Journal of Chemical Information and Modeling, Vol. 43, No. 2, 2003, pp. 651-655. doi:10.1021/ci025625q

[13] J. F. Howes and C. Bell, “Talampanel,” Neurotherapeutics, Vol. 4, No. 1, 2007, pp. 126-129. doi:10.1016/j.nurt.2006.11.001

[14] R. Gitto, R. Caruso, V. Orlando, S. Quartarone, M. L. Barreca, G. Ferreri, E. Russo, G. D. Sarro and A. Chimirri, "Synthesis and Anticonvulsant Properties of Tetrahydroisoquinoline Derivative,” Farmaco, Vol. 59, No. 1, 2004, pp. 7-12. doi:10.1016/j.farmac.2003.10.003

[15] R. Gitto, R. Caruso, B. Pagano, L. D. Luca, R. Citraro, E. Russo, G. D. Sarro and A. Chimirri, "Novel Potent Anticonvulsant Agent Containing a Tetrahydroisoquinoline Kkeleton,” Journal of Medicinal Chemistry, Vol. 49, No. 18, 2006, pp. 5618-5622. doi:10.1021/jm060411b

[16] R. Gitto, B. Pagano, R. Citrato, F. Scicchitano, G. D. Sarro and A. Chimirri, "Solution-Phase Parallel Synthesis and Evaluation of Anticonvulsant Activity of N-Substituted3,4-dihydroisoquinoline-2(1H)-carboxamides," European Journal of Medicinal Chemistry, Vol. 44, No. 3, 2009, pp. 1349-1354. doi:10.1016/j.ejmech.2008.02.025

[17] L. De Luca, R. Gitto, M. L. Barreca, R. Caruso, S. Quartarone, R. Citraro, G. D. Sarro and A. Chimirri, "3D Pharmacophore Models for 1,2,3,4-Tetrahydroisoquinoline Derivatives Acting as Anticonvulsant Agents," Archiv der Pharmazie Chemistry in Life Sciences, Vol. 339, No. 7, 2006, pp. 388-400.
[18] K. J. Bough and D. A. Engel, "Comparison of the Anticonvulsant Efficacies and Neuroroxic Effects of Valproic Acid, Phehytoin, and the Ketogenic Diet," Epilepsia, Vol. 42, No. 10 , 2001, pp. $1345-1353$. doi:10.1046/j.1528-1157.2001.08901.x

[19] J. B. Monent, I. Jorquera, I. Mazzucchelli, A. Depaulis, E. Perucca, Y. Ben-Ari and A. Represa, "Fetal Exposure to GABA-Acting Antiepileptic Drugs Generates Hippocampal and Cortical Dyspkasias,” Epilepsia, Vol. 48, No. 4, 2007, pp. 684-693. doi:10.1111/j.1528-1167.2007.01056.x

[20] V. B. Brito, V. Folmer, G. O. Puntel, R. Fachinetto, J. C. Soares, G. Zeni, C. W. Nogueira and J. B. Rocha, "Diphenyl Diselenide and 2,3-Dimercaptopropanol Increase the PTZ-Induced Chemical Seizure and Mortality in Mice," Brain Research Bulletin, Vol. 68, No. 6, 2006, pp. 414418.

[21] A. Ilhan, M. A. Aladag, A. Kocer, A. Boluk, A. Gurel and F. Armutcu, "Erdosteine Ameliorates PTZ-Induced Oxidative Stress in Mice Seizure Model," Brain Research Bulletin, Vol. 30, No. 6, 2005, pp. 495-499. doi:10.1016/j.brainresbull.2005.02.027

[22] N. B. Agarwal, S. Jain, D. Nagpal, N. K. Agarwal, P. K. Mediratta and K. K. Sharma, "Liposomal Formulation of Curcumin Attenuates Seizures in Different Experimental Models of Epilepsy in Mice," Fundamental \& Clinical Pharmacology, 2011. doi:10.1111/j.1472-8206.2011.01002.x

[23] A. Zandieh, F. Maleki, A. Hajimirzabeigi, B. Zandieh, O. Khalilzadeh and A. R. Dehpour, "Anticonvulsant Effect of Celecoxib on Pentylenetetrazole-Induced Convulsion: Modulation by NO Pathway," Acta Neurobiologiae Experimentalis, Vol. 70, No. 4, 2010, pp. 390-397. 